О. П. Кириленко,

д. е. н., професор, завідувач кафедри фінансів ім. С. I. Юрія,

Тернопільський начіональний економічний університет, м. Тернопіль

О. С. Максимчук,

аспірант кафедри фінансів імені С. I. Юрія,

Тернопільський начіональний економічний університет, м. Тернопіль

DOI: $10.32702 / 2306-6814.2019 .2 .5$

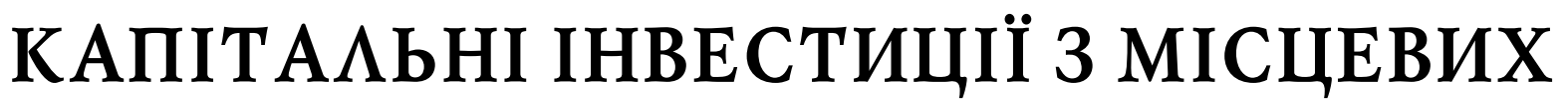 БЮАЖЕТІВ: СУЧАСНА ПРАКТИКА ТА ПЕРСПЕКТИВИ УАОСКОНААЕННЯ
}

\author{
O. Kyrylenko, \\ Doctor of Economic Sciences, Proffesor, Head of the Department \\ of Finance named after S. Yuriy, Ternopil national economic university, Ternopil \\ O. Maksymchuk, \\ Post-graduate student of the Department of Finance \\ named after S. Yuriy, Ternopil national economic university, Ternopil
}

\section{CAPITAL INVESTMENTS FROM LOCAL BUDGETS: MODERN PRACTICE AND PROSPECTS FOR IMPROVEMENT}

Устатті розглянуто підходи українських науковців до трактування поняття бюджетних інвестицій. Сформульовано авторське визначення цього поняття. Обгрунтовано роль бюджетних інвестицій в економіці на основі функцій, які вони виконують. Проведено аналіз основних показників, що характеризують стан капітального інвестування з місцевих бюджетів в Україні: питома вага капітальних інвестицій з місцевих бюджетів узагальному обсязі інвестицій та в структурі капітальних видатків місцевих бюджетів, а також регіональна диференціація за показником капітальних інвестицій з місцевих бюджетів у розрахунку на 1 особу. На основі такого аналізу виявлено позитивні та негативні сторони в забезпеченні капітальних видатків з місцевих бюджетів та запропоновано напрями удосконалення інституційного забезпечення цього інституту в Україні, що дозволять збільшити його ефективність.

The article considers the approaches of Ukrainian scientists to the definition of budgetary investments. The author's definition of is formulated: investing of budget funds of all levels in the creation, restoration and modernization of long-term tangible assets in order to obtain economic and social benefits and/or increase budget revenues in the future. The role of the budget investments in the economy are substantiated through the main functions that they perform. The analysis of the main indicators describing the situation with the capital investments from local budgets in the general structure of investments and in the structure of local budgets' capital expenditures, as well as regional differentiation of capital investments from local budgets per capita. On the basis of this analysis, positive and negative aspects in providing capital investments from local budgets have been identified:

Positive:

- growth of volume of capital investments from local budgets both in the country as a whole and in the regions;

- an increase in the share of capital investment from local budgets in the total volume of capital investments in the country; 
- increase in the proportion of capital investment in capital expenditures of local budgets.

Negative:

- significant uneven rates of investment growth between regions;

- high level of regional disproportions;

- increase in the level of concentration of capital investments in a limited number of regions

Directions of improvement of institutional support of this institute in Ukraine that increase its effectiveness has been proposed:

- the legal definition of the concept of "budgetary investments";

- implementation of medium-term planning;

- ensuring the stability of the annual capital expenditures;

- separation of planning of development budget from similar procedures concerning to the current budget.

Ключові слова: бюджетні інВестиції, капітальні інВестиції, капітальні видатки, місцевий бюджет, бюджет розвитку.

Key words: budget investments, capital investments, capital expenditures, local budget, development budget.

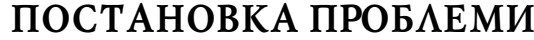

В Україні впродовж останніх десятиліть склалася надзвичайно складна ситуація з оновленням основних орондів, що вимагає здійснення бюджетних видатків, розрахованих на тривалу перспективу, та переходу до інвестиційно орієнтованого бюджетування. В умовах трансформаційних змін одним із першочергових пріоритетів $є$ прискорення інноваційного розвитку та технічне й технологічне відновлення виробничих потужностей реального сектора економіки, що вимагає забезпечення державою сприятливого інвестиційного клімату. Зважаючи на це, важливо, по-перше, забезпечити збалансований розподіл у часі обсягів благ, які отримує суспільство, та податкового навантаження, а по-друге, правильно та ефективно визначити структуру видатків, які генеруватимуть блага в майбутньому для того, щоб вони максимально відповідали сучасним пріоритетам. Визначальна роль у цьому процесі відводиться бюджетам різних рівнів, особливо місцевим. Тому особливої актуальності набуває проблема підвищення ефективності використання коштів місцевих бюджетів з метою активізації інвестиційної діяльності та збільшення обсягів капітальних інвестицій. Саме із зазначених причин постає необхідність аналізу стану капітальних інвестицій з місцевих бюджетів, визначення наявних тенденцій та вироблення рекомендацій щодо вдосконалення чинної практики капітального інвестування.

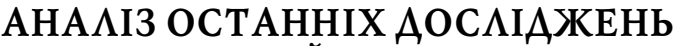 ТА ПУБАІКАЦІЙ}

Дослідженням теоретичних та практичних аспектів бюджетних інвестицій займається ряд українських науковців, як-от: Баніт Ю.В. [1], Затонацька Т.Г. [2], Кулешір
В.В. [3], Малиняк Б.С. [4], Михайленко С.В. [5], Попель Л.А. [6], Радіонов Ю.Д. [7], Сіденко В.Р. [8], Ставицький А.В. [2] та інші. Разом з тим, недостатньо розробленими залишаються питання бюджетного інвестування за рахунок коштів місцевих бюджетів у нових умовах рефрормування місцевого самоврядування та проведення бюджетної децентралізації.

\section{META АОС $А$ АЖЕННЯ}

Метою дослідження $є$ поглиблення розуміння сутності бюджетних інвестицій, виявлення тенденцій капітального інвестування за рахунок коштів місцевих бюджетів та проблем, які характерні для цієї сорери та розробка рекомендацій щодо підвищення ефективності капітального інвестування з місцевих бюджетів.

\section{ВИК ААА ОСНОВНОГО МАТЕРІААУ АОС АІАЖЕННЯ}

Фінансово-економічна криза, значні інфрляційні очікування та фрінансова нестабільність негативно впливають на інвестиційний клімат держави. Як наслідок, зумовлюють зростання кредитних ставок комерційних банківських установ, що призводить до зменшення їх кредитної бази та обмеження можливостей у кредитуванні реального сектора економіки. Тому в цій ситуації бюджет залишається одним з основних джерел капітальних інвестицій з метою задоволення життєво важливих для країни інноваційних проектів.

У трактуванні сутності капітальних інвестицій у науковій літературі немає єдиного підходу; вчені по-різному визначають специфрічні характеристики даного поняття, акцентуючи на різних його аспектах. Так, на думку Баніт Ю.В., під бюджетними інвестиціями слід розуміти 


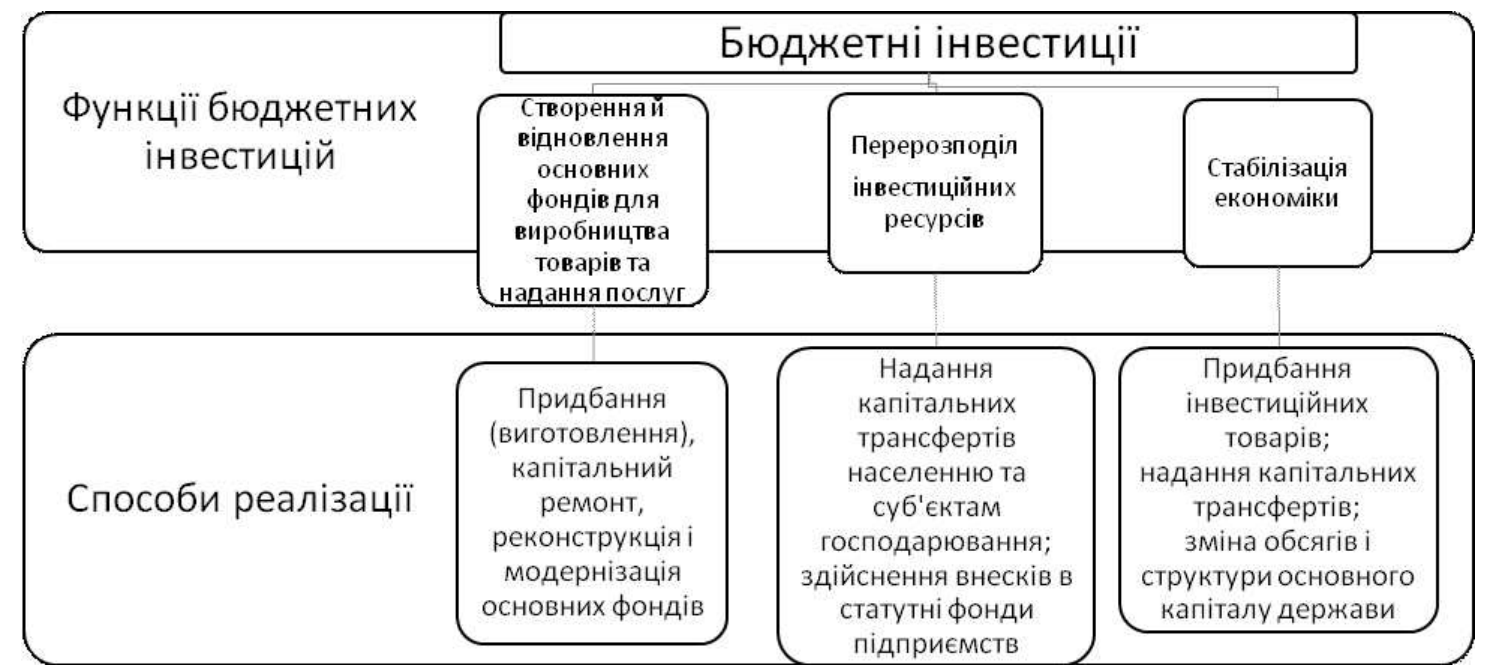

Рис. 1. Функції та інструменти бюджетних інвестицій

Джерело: складено авторами на основі [4, с. 9].

вкладення, інвестором котрих $є$ держава, що виділяє кошти для фрінансування інвестиційних проектів, а під бюджетним інвестуванням - процес вкладення у грошовій та натуральній формах коштів, які спрямовують на розширене відтворення основних фрондів, людського капіталу, збільшення державних активів, реалізацію загальнодержавних цілей [1, с. 78]. При цьому автор розглядає бюджетні інвестиції виключно стосовно державного бюджету.

Михайленко С.В., визначаючи бюджетні інвестиції як вкладення (переважно, довгострокові), які проводяться за рахунок бюджетних коштів, підкреслює отримання певних соціально-економічних ефектів від бюджетних інвестицій у майбутньому [5, с. 108]. Радіонов Ю.Д. деталізує напрямки вкладень та очікувані ефекти бюджетних інвестицій та визначає їх як видатки бюджету, направлені на реалізацію різноманітних бюджетних програм (від науково-технічних до соціально-економічних), пріоритетів розвитку регіонів тощо з метою забезпечення зростання вартості основних фондів, державних активів, підвищення рівня життя населення та соціальноекономічного розвитку країни в цілому [7, с. 39].

На нашу думку, під бюджетними інвестиціями слід розуміти вкладення коштів бюджетів усіх рівнів у створення, відновлення та модернізацію матеріальних активів довготривалого користування з метою отримання економічних і соціальних ефектів та/або збільшення доходів бюджетів у майбутньому.

Домінантою бюджетного інвестування виступає система економічних та соціальних потреб території, на задоволення яких, власне, і мають спрямовуватися бюджетні та інвестиційні ресурси. Однак кошти повинні використовуватися не на поточні потреби території, т.б. на споживання, а на стратегічні, які повинні забезпечуватися за рахунок видатків інвестиційного характеру. Основні вимоги щодо фрінансування таких стратегічних видатків визначені в Законі України "Про місцеве самоврядування в Україні", зокрема акцентовано на напрямах спрямування коштів бюджету розвитку місцевих бюджетів на реалізацію програм соціально-економічного розвитку відповідної території, пов'язаних із здійсненням інвестиційної й інноваційної діяльності, надан- ням субвенцій та інших видатків щодо розширеного відтворення [9].

Фінансування видатків на соціальний та економічний розвиток може відбуватися як за рахунок державного, так і місцевих бюджетів, тому важливою $є$ потреба розподілу повноважень щодо їх реалізації між різними рівнями бюджету. У вирішенні питання задоволення суспільних потреб за рахунок бюджетних коштів слід зважити на те, що при децентралізованому підході $\epsilon$ можливість повніше врахувати інтереси споживачів, а при переході до централізованого забезпечення - знизити вартість послуг. На практиці при визначенні рівня бюджету, з якого потрібно фінансувати видатки для забезпечення суспільних потреб, керуються принципом субсидійності, згідно якого найбільшої ефективності у виконанні тієї чи іншої видаткової функції можна досягти у тому разі, якщо вона буде закріплена за нижчим із тих рівнів влади, котрі можуть реалізовувати її належним чином. Так, за висновками Затонацької Т.Г. та Ставицького А.В., інвестиції з місцевих бюджетів мають найбільшу ефективність впливу на зростання ВВП [2, с. 52]. У свою чергу, державні інвестиції мають найнижчі показники ефективності впливу на соціальну складову розвитку, що підтверджує пріоритетність розвитку інвестиційної складової місцевих бюджетів. Крім того, результати інших досліджень підтверджують, що збільшення бюджетних інвестицій у розмірі еквівалентному $1 \%$ ВВП (у першу чергу - в інфрраструктурні проекти) дозволяє збільшити податкові доходи бюджету наступного та другого року після їхнього здійснення на 15-17 млрд грн [8, с. 193].

Доречно зазначити, що інвестування бюджетних коштів, з однієї сторони, може супроводжуватись економічними ризиками та втратою бюджетних коштів, 3 іншої сторони, досягненням максимального економічного та соціального ефекту в майбутньому. Забезпечення позитивного результату інвестування бюджетних коштів можливе за умови дотримання основних вимог та правил інвестування, до яких слід віднести:

- формування достатніх бюджетних інвестиційних ресурсів для реалізації інвестиційних програм та проектів; 
Таблиця 1. Динаміка частки капітальних інвестицій з місцевих бюджетів України у сукупних обсягах капітальних інвестицій за 2014-2017 рр., млрд грн

\begin{tabular}{|l|l|l|l|l|}
\hline \multicolumn{1}{|c|}{ Показники } & \multicolumn{4}{c|}{ Роки } \\
\cline { 2 - 5 } & 2014 & 2015 & 2016 & 2017 \\
\hline $\begin{array}{l}\text { Капітальні інвестиції, всього, } \\
\text { млрд грн }\end{array}$ & 219,5 & 273,1 & 359,2 & 448,5 \\
\hline Темпи зростання, \% & $\mathrm{x}$ & 124,4 & 131,5 & 124,9 \\
\hline $\begin{array}{l}\text { Капітальні інвестиції з } \\
\text { місцевих бюджетів, млрд грн }\end{array}$ & 5,9 & 14,3 & 26,8 & 41,6 \\
\hline Темпи зростання, \% & $\mathrm{x}$ & 242,4 & 187,4 & 155,2 \\
\hline Рівень інфляції & 112,1 & 148,7 & 113,9 & 114,4 \\
\hline $\begin{array}{l}\text { Частка інвестицій з місцевих } \\
\text { бюджетів, у \% до загального } \\
\text { обсягу інвестицій }\end{array}$ & 2,69 & 5,24 & 7,46 & 9,28 \\
\hline
\end{tabular}

Джерело: складено авторами на основі даних Державної служби статистики України [11].

\section{Таблиця 2. Питома вага капітальних інвестицій у структурі капітальних видатків місцевих} бюджетів у 2014-2017 рр., \%

\begin{tabular}{|l|l|l|l|l|}
\hline & 2014 & 2015 & 2016 & 2017 \\
\hline $\begin{array}{l}\text { Капітальні видатки місцевих } \\
\text { бюджетів, млрд грн }\end{array}$ & 13,9 & 32,2 & 52,6 & 74,3 \\
\hline $\begin{array}{l}\text { Капітальні інвестиції з } \\
\text { місцевих бюджетів, млрд грн }\end{array}$ & 5,9 & 14,3 & 26,8 & 41,6 \\
\hline $\begin{array}{l}\text { Питома вага капітальних } \\
\text { інвестицій у капітальних } \\
\text { видатках місцевих бюджетів, \% }\end{array}$ & 42,4 & 44,4 & 51,0 & 56,0 \\
\hline
\end{tabular}

Джерело: складено авторами на основі даних Державної служби статистики України [11] та Державної казначейської служби України [12].

- підбір найбільш пріоритетних інвестиційних програм та проектів, які в майбутньому дадуть позитивний есрект;

- відбір на конкурсній основі виконавців інвестиційних проектів з врахуванням того факту, щоб за мінімальних витрат досягти максимального ефекту;

- використання інвестиційних коштів за призначенням;

- постійний державний контроль за фрормуванням та використанням бюджетних інвестиційних ресурсів;

- недопущення правопорушень в процесі фрінансування інвестиційних програм та проектів [6, с. 207].

Сутність бюджетних капітальних інвестицій більш детально проявляється у функціях, які вони виконують. Колектив авторів монографії "Інституційна трансфрормація фрінансово-економічної системи України в умовах глобалізації" виділяє 3 основних фрункції інституту інвестування: стимулююча (створення умов для підвищення активності процесів капіталовкладень), інтеграційна (гармонізація й узгодження суперечливих інтересів суб'єктів інвестиційної діяльності), інноваційна (оновлення економічних ресурсів іїх якісний розвиток, використання прогресивних організаційних фрорм та методів управління тощо) [8, с. 261-262]. Ці фрункції стосуються загалом інвестицій, як інституту. Домінантою ж бюджетних інвестиції як специфрічного елементу даного інституту $є$ функції створення та відновлення основних фондів для виробництва товарів та надання послуг; перерозподілу інвестиційних ресурсів; стабілізації економіки. Способи реалізації зазначених функцій представлено на рисунку 1.

Застосування механізму бюджетного інвестування дає змогу коригувати галузеву та територіальну структуру основних фрондів. Суть перерозподільчої фрункції бюджетних інвестицій полягає у тому, що за їх допомо- гою можна впливати на обсяги основних фрондів окремих галузей або територій шляхом перерозподілу сукупних бюджетних ресурсів. Реалізація цієї функції відбувається, зокрема, завдяки встановленню зв'язку між надходженнями від відчуженням об'єктів державної та комунальної власності та ресурсами, які направляються у вигляді капітальних трансорертів суб'єктам господарювання.

Слід зазначити, що видатки інвестиційного характеру мають здатність стабілізуюче впливати на амплітуду циклічних коливань економіки. Так, за допомогою таких видатків можна отримати як короткостроковий, так і довгостроковий стабілізуючий ефрект, які описав видатний економіст XX ст. Дж. Кейнс: "збільшення реального доходу, зайнятості та інвестицій можна досягти за допомогою достатньо великого автономного збільшення споживання, інвестицій або державних витрат" [10, с. 245]. Серед цих трьох напрямів стимулювання суспільного виробництва особлива роль відводиться інвестиціям. Це пояснюється дією мультиплікатора, яка полягає у впливі приросту інвестицій на прискорення зростання доходів [3, с. 125].

Основна мета капітальних бюджетних інвестицій полягає в інвестиційному забезпеченні розвитку економіки та соціальної сорери. Відповідно, передбачається інвестування коштів у формування такої системи надання суспільних послуг, яка би забезпечувала високий рівень соціально-економічного розвитку, підвищувала матеріальний добробут населення, забезпечувала розвиток матеріально-технічної бази соціальної сорери, а також активізувала інвестиційні процеси та сприяла економічному зростанню в країні.

Позитивний соціальний ефект бюджетного інвестування, за висновками Попель Л.А., виражається через показники: 
Таблиця 3. Динаміка капітальних інвестицій місцевих бюджетів на 1 особу наявного населення*, грн

\begin{tabular}{|c|c|c|c|c|c|c|}
\hline & & \multicolumn{4}{|c|}{ Роки } & \multirow{2}{*}{$\begin{array}{c}\text { Темп } \\
\text { росту, } \\
2017 / 2014, \\
\%\end{array}$} \\
\hline & 2013 & 2014 & 2015 & 2016 & 2017 & \\
\hline Вінницька обл. & 166,5 & 197,9 & 359,7 & 488,2 & 1014,6 & 609,5 \\
\hline Волинська обл. & 239,2 & 210,3 & 341,5 & 546,7 & 646,9 & 270,4 \\
\hline Дніпропетровська обл. & 135 & 105,6 & 411,6 & 719,3 & 1239 & 917,9 \\
\hline Донецька обл. & 149,2 & 80,9 & 97,6 & 244,4 & 463,2 & 310,4 \\
\hline Житомирська обл. & 197,7 & 222,6 & 342,1 & 579,7 & 624,5 & 315,8 \\
\hline Закарпатська обл. & 111,2 & 130,5 & 328,2 & 452,8 & 525,7 & 473,0 \\
\hline Запорізька обл. & 138,2 & 105,8 & 400,8 & 723,6 & 785,1 & 568,2 \\
\hline $\begin{array}{l}\text { Івано-Франківська } \\
\text { обл. }\end{array}$ & 115,7 & 171,3 & 418 & 663,5 & 906,9 & 783,6 \\
\hline Київська обл. & 71,2 & 69,8 & 191,5 & 476,8 & 615,5 & 864,6 \\
\hline Кіровоградська обл. & 138,6 & 121,2 & 334,9 & 499,8 & 805,8 & 581,2 \\
\hline Луганська обл. & 157,6 & 33,4 & 120,9 & 259,1 & 462,9 & 293,7 \\
\hline Львівська обл. & 116,9 & 87,4 & 298 & 522,1 & 737,8 & 631,3 \\
\hline Миколаївська обл. & 120,3 & 87,5 & 258,5 & 644,5 & 792,1 & 658,3 \\
\hline Одеська обл. & 155,5 & 182,3 & 417,2 & 941,7 & 1540,4 & 990,7 \\
\hline Полтавська обл. & 139,6 & 104 & 317,7 & 650,6 & 1087,7 & 779,4 \\
\hline Рівненська обл. & 178,8 & 178,4 & 306,2 & 499,8 & 606,4 & 339,2 \\
\hline Сумська обл. & 107,2 & 134,7 & 273,5 & 542,5 & 777,2 & 724,9 \\
\hline Тернопільська обл. & 128,9 & 146,5 & 266,1 & 430,7 & 488,1 & 378,7 \\
\hline Харківська обл. & 201 & 208,2 & 462,4 & 956,3 & 1321,3 & 657,4 \\
\hline Херсонська обл. & 118,7 & 145,2 & 303 & 492,1 & 564,7 & 475,7 \\
\hline Хмельницька обл. & 129,2 & 156,4 & 414,7 & 563,3 & 805,9 & 623,6 \\
\hline Черкаська обл. & 171 & 157,2 & 295,5 & 630 & $* *$ & - \\
\hline Чернівецька обл. & 121,5 & 159,8 & 329,8 & 566,7 & 636 & 523,6 \\
\hline Чернігівська обл. & 95,5 & 113,9 & 224,1 & 461,5 & 825,4 & 864,7 \\
\hline м. Київ & 357 & 236,4 & 700,5 & 1454,7 & 2951,7 & 826,8 \\
\hline $\begin{array}{l}\text { В середньому по } \\
\text { Україні }\end{array}$ & 149,4 & 137,6 & 332,8 & 628,4 & 978,4 & 654,8 \\
\hline
\end{tabular}

* Складено авторами на основі даних Державної служби статистики України [11] та її територіальних органів [13].

** Дані відсутні.

- підвищення рівня надання суспільних послуг у сорері освіти, охорони здоров'я, соціального захисту населення, культури та мистецтва, фрізичної культури і спорту, житлово-комунального та дорожнього господарства;

- розвитку місцевої інфрраструктури, особливо територіальних громад нижчого рівня, з метою отримання корисного суспільного ефекту в майбутньому;

- обсягів соціальної підтримки жителів міст, сіл, селищ України та забезпечення соціальних гарантій відповідно до встановлених соціальних стандартів та законодавчо визначених нормативів;

- підвищення рівня життя громадян, покращення житлово-комунальних умов, забезпечення зайнятості населення;

- збільшення обсягів державного житлового будівництва та мінімізація витрат на спорудження житла та введення його в експлуатацію;

- поліпшення навколишнього природного середовища [6, с. 208].

Джерелом бюджетних інвестицій виступають капітальні видатки місцевих бюджетів, т.б. видатки бюджетів на фрінансування інвестиційної та інноваційної діяльності, капітальні вкладення виробничого і невиробничого призначення, структурну перебудову місцевого господарства. Капітальні видатки місцевих бюджетів, за чинною практикою, здійснюються за рахунок бюджету розвитку.

Важливим показником, який демонструє результативність освоєння капітальних інвестицій з місцевих бюджетів, $є$ частка капітальних інвестицій місцевих бю-

джетів у загальному обсязі капітальних інвестицій в країні (табл. 1).

Наведені у таблиці дані підтверджують зростання усіх якісних та кількісних показників капітальних інвестицій місцевими бюджетами. Так, за 2014-2017 рр. зросли абсолютні розміри капітальних інвестицій місцевих бюджетів більше ніж у 7 разів, збільшилася їх частка у загальному обсязі капітальних інвестицій по країні (більш ніж у 3 рази). Це стало наслідком передачі на місця набагато більшого обсягу повноважень у сфері капітального інвестування. Слід відмітити, що капітальні інвестиції з місцевих бюджетів, згідно з дослідженнями вітчизняних вчених мають потужніший вплив на зростання ВВП, порівняно з капітальними інвестиціями 3 інших джерел. При цьому ще однією позитивною тенденцією, яку можна відмітити є перевищення темпів зростання капітальних видатків місцевих бюджетів над темпами інфляції. Це свідчить про реальне, а не лише номінальне зростання інвестиційного ресурсу, що $є$ у наявності місцевої влади.

Позитивною тенденцією є зростання частки капітальних інвестицій у структурі капітальних видатків місцевих бюджетів (табл. 2), що свідчить про посилення ролі бюджету розвитку місцевих бюджетів та спрямування більшого обсягу бюджетних ресурсів на створення та оновлення основних фондів. В умовах наявних кризових явищ такі тенденції $€$ необхідною умовою для активізації підприємницької інвестиційної активності, оздоровлення інвестиційного клімату, оновлення основних фондів та забезпечення економічного зростання, адже стан зносу активів та інфрраструктури $\epsilon$ 
загрозливо високим і саме завдяки інвестиціям цю ситуацію можна виправити.

3 наведених даних можна зробити висновок про зростання усіх якісних та кількісних показників, що характеризують стан капітального інвестування з місцевих бюджетів. Ця тенденція дає підстави стверджувати, що політика децентралізації позитивно впливає на зростання інвестиційної активності місцевих бюджетів. Разом 3 тим, необхідно проаналізувати регіональні відмінності, що мають місце при здійсненні капітальних інвестицій. Для цього розглянемо показники обсягу капітальних інвестицій в розрахунку на 1 особу наявного населення в розрізі регіонів у таблиці 3.

Як видно з даних таблиці, капітальні інвестиції з місцевих бюджетів в усіх регіонах у 2013-2017 рр. зростали, разом з тим, зростання було нерівномірним в регіональному розрізі. Найбільші темпи росту характерні для Одеської (в 9,9 разів) та Дніпропетровської областей (9,2 рази), а найменші - для Волинської (2,7 рази), Луганської (2,9 рази) та Донецької областей (3, 1 рази). Найвище значення зазначеного відносного показника капітальних інвестицій з місцевих бюджетів в усі роки спостерігалося в м. Києві, причому розрив між показниками столиці та наступного за рейтингом регіону щороку лише збільшувалося. Найнижчими капітальні інвестиції з місцевих бюджетів у розрахунку на 1 особу в 2013 році були в Київській та Чернігівській областях, а починаючи з 2014 року - у Донецькій та Луганській областях. Можна виділити кілька чинників, що спричинили таку динаміку аналізованого показника - це, зокрема, окупація частини території країни та проведення АТО. Так, на території Донецької області значення показника капітальних інвестицій на одну особу зменшилося в 2014 році майже вдвічі порівняно 3 2013 роком, а в Луганській - майже в 5 раз. Крім того, це спричинило загальний спад інвестицій з усіх джерел, що також позначилось на їх загальній динаміці.

Негативною тенденцією, як видно з даних таблиці, $€$ нестабільність обсягів фінансування інвестицій та існування значних коливань аналізованих показників в розрізі конкретно взятих регіонів. Так, найбільші показники щороку перевищують найнижчі приблизно у 5-7 разів. Крім цього, показовим є той фракт, що впродовж даного періоду кількість регіонів, де капітальні інвестиції в розрахунку на 1 особу населення перевищують середнє значення по країні, знизилася з 13 до 6. Водночас кількість регіонів, у яких значення цього показника було більше ніж вдвічі нижчим за середнє по країні, впродовж аналізованого періоду зросла з 1 до 3. Таким чином, ми спостерігаємо не лише високий рівень регіональних диспропорцій, ай його постійне зростання.

Як бачимо з проведеного аналізу, сучасний стан здійснення капітальних інвестицій з місцевих бюджетів характеризується як позитивними, так і негативними тенденціями. Негативним на нашу думку є:

- значна нерівномірність темпів зростання обсягів інвестицій між регіонами;

- високий рівень регіональних диспропорцій;

- зростання рівня концентрації капітальних інвестицій в обмеженій кількості регіонів.

До позитивних тенденцій слід віднести: зростання обсягу капітальних інвестицій з місцевих бюджетів як загалом по країні, так і в розрізі регіонів; збільшення частки капітальних інвестицій з місцевих бюджетів у загальному обсягу капітальних інвестицій в країні.

\section{ВИСНОВКИ}

Однією з ключових проблем сучасної регіональної економіки України є суттєва диференціація територій за економічними, соціальними і за суспільно-політичними параметрами розвитку. Це спричинює та поглиблює диспропорції у розвитку окремих регіонів. Вони обумовлені тим, що в період розгортання ринкових трансформацій зусилля держави були спрямовані на забезпечення стабілізації макроекономічної ситуації, а це доволі часто суперечило інтересам збалансованого регіонального розвитку. Наявність значних регіональних соціально-економічних диспропорцій:

- перешкоджає проведенню єдиної соціальної і економічної політики;

- збільшує загрози регіональних криз, дезінтеграції національної економіки;

- створює перешкоди для повноцінного використання наявного потенціалу міжрегіонального співробітництва.

У цих умовах бюджетні інвестиції можуть стати ефективним інструментом усунення вказаних недоліків. Однак, не зважаючи на численні наукові дослідження, в чинному законодавстві досі немає визначення поняття "бюджетні інвестиції". Тому вважаємо формулювання законодавчого визначення поняття бюджетних інвестицій шляхом внесення відповідних змін до Бюджетного кодексу України та закону України "Про інвестиційну діяльність" одним з найважливіших кроків у цій сорері для забезпечення подальшого розвитку цього інституту.

Загалом, капітальні інвестиції місцевих бюджетів $\epsilon$ реальним фрінансовим інструментом активізації інвестиційної діяльності в країні. Слід зазначити, що бюджетні інвестиції мають перспективний характер, тому можуть сприяти реалізації довгострокових цілей за умов сталого фрінансування запланованих відповідними програмами і проектами заходів впродовж тривалого проміжку часу. Інвестиційні проекти можна планувати і реалізовувати протягом декількох років і в кілька етапів, що дає змогу заощаджувати кошти на великі програми або розподіляти витрати на них більш рівномірно у часі.

Тому, на нашу думку, не варто обмежувати планування бюджету розвитку одним бюджетним роком. Важливоює розробка стратегічних завдань за допомогою регіональних інвестиційних програм, яким притаманні проектний підхід, несуперечливість поточних та довгострокових видатків, інтегрованість у систему середньострокового бюджетного планування. Перші кроки в цьому напрямі вже здійснені, так, Верховною Радою України 06.12.2018 року прийнято закон "Про внесення змін до Бюджетного кодексу України (щодо правового підгрунтя для запровадження середньострокового бюджетного планування)". Цей закон створив базис для середньострокового планування. Важливо забезпечити подальший розвиток концептуальних положень закону, що дозволить створити методичне підгрунття середньострокового планування та повноцінно інтегрувати його в діяльність органів влади усіх рівнів. 
Крім цього, важливим є забезпечення стабільності капітальних видатків з місцевих бюджетів, що спрямовані на реалізацію запланованих капітальних проектів. Так, відповідно до чинного законодавства, у разі неприйняття місцевого бюджету до початку бюджетного періоду, можуть фрінансуватися лише захищені статті видатків. Водночас вважаємо за доцільне дозволити здійснювати також капітальні видатки по тих проектах, які реалізовувалися в попередніх бюджетних періодах, однак, видатки по нових проектах потрібно дозволяти лише після затвердження місцевого бюджету. Довгострокове планування капітальних видатків дозволяє обгрунтувати такі видатки у випадку невчасного прийняття місцевого бюджету.

Найпершим кроком, без якого неможливе забезпечення достатньої ефективності попередніх заходів, має бути відокремлення процесів планування і прийняття бюджету розвитку від аналогічних процедур щодо поточного бюджету, це пояснюється кількома причинами:

- капіталовкладення досить часто фрінансуються 3 цільових разових джерел;

- $є$ відмінність у процесах прийняття рішень щодо річного та середньострокового бюджетів; жетів;

- суттєвою $є$ відмінність часових рамок цих бюд-

- ускладнення "ручного" перерозподілу коштів 3 фрінансування капітальних видатків на здійснення поточних видатків.

Реалізація запропонованих заходів дозволить забезпечити більш ефективне капітальне інвестування 3 місцевих бюджетів шляхом створення нормативно-правового поля для бюджетного інвестування та підвищення якості процесу планування капітальних інвестицій $з$ місцевих бюджетів.

Література:

1. Фінансова політика інвестиційно-інноваційного розвитку України: монографрія / В.Г. Дем'янишин та ін. - Тернопіль: ТНЕУ, 2014. - 464 с.

2. Затонацька Т.Г., Ставицький А.В. Дослідження впливу інвестицій на економічне зростання в Україні за допомогою фронометричного аналізу / / Наукові праці НДФІ. - 2007. - № 1 (38). - С. 49-55.

3. Кулешір В.В. Диверсифрікація джерел формування місцевих бюджетів розвитку. Вісник Дніпропетровського університету. Серія "Економіка". - 2011. - № 5 (3). - С. 124-132.

4. Кириленко О.П., Малиняк Б.С. Теорія і практика бюджетних інвестицій: монографрія. - Тернопіль: Економічна думка, 2007. - 288 с.

5. Михайленко С.В. Бюджетний менеджмент: стан та оцінка ефрективності: монографрія. - Одеса: ВМВ: Друк Південь, 2010. - 398 с.

6. Попель Л.А. Бюджетні інвестиції як складова інвестицій реального сектору економіки // Вісник Хмельницького національного університету. - 2011. № 2. - Т. 3. - С. 205-209.

7. Радіонов Ю.Д. Бюджетні кошти як інвестиційний ресурс України / / Економіка України. - 2014. - № 9 (634). - С. 35-53.

8. Інституційна трансформація фрінансово-економічної системи України в умовах глобалізації: монографрія / В.Р. Сіденко та ін. - Київ: КНТЕУ, 2017. - 648 с.
9. Про місцеве самоврядування в Україні: Закон України від 21.05.1997 р. № 280/97-ВР (у ред. від 04.11.2018 p.). URL: http://zakon3.rada.gov.ua/laws/ show $/ 280 / 97-$ вр

10. Блауг М. Економічна теорія в ретроспективі / Пер. $з$ англ. І. Дзюб. - К.: Вид-во Соломії Павличко "Основи", 2001.670 с.

11. Державна служба статистики України. URL: http://ukrstat.gov.ua/

12. Звітність. Державна казначейська служба України. URL: https://www.treasury.gov.ua/ua/file-storage/vikonannya-derzhavnogo-byudzhetu

13. Територіальні органи статистики України. URL: http://www.ukrstat.gov.ua/work/region.html

References:

1. Dem'ianyshyn, V. H. (2014), Finansova polityka investytsijno-innovatsijnoho rozvytku Ukrainy [The financial policy of investment and innovation development of Ukraine], TNEU, Ternopil, Ukraine.

2. Zatonats'ka, T. H. and Stavyts'kyj, A. V. (2007), "A study of the impact of investments on the economic growth in Ukraine using fonometric analysis". Naukovi pratsi NDFI, Vol. 1 (38), pp. 49-55.

3. Kuleshir, V. V. (2011), "Diversification of sources of local development budget", Visnyk Dnipropetrovs'koho Universytetu. Seriia "Ekonomika", Vol. 5 (3), pp. 124-132.

4. Kyrylenko, O. P. and Malyniak, B. S. (2007), Teoriia i praktyka biudzhetnykh investytsij [Theory and practice of budget's investments], Ekonomichna dumka, Ternopil, Ukraine.

5. Mykhajlenko, S. V. (2010), Biudzhetnyj menedzhment: stan ta otsinka efektyvnosti [Budget management: situation and evaluation of the effectiveness], VMV: Druk Pivden', Odesa, Ukraine.

6. Popel', L. A. (2011), "Budgetary investments as part of investment of the real economy", Visnyk Khmel'nyts'koho natsional'noho universytetu, Vol. 2, no. 3, pp. 205-209.

7. Radionov, Yu. D. (2014), "Budget funds as an investment resource of Ukraine", Ekonomika Ukrainy, Vol. 9 (634), pp. 35- 53.

8. Sidenko, V. R. (2017), Instytutsijna transformatsiia finansovo-ekonomichnoi systemy Ukrainy $v$ umovakh hlobalizatsii [Institutional transformation of the economic and financial system of Ukraine under globalization], KNTEU, Kyiv, Ukraine.

9. The Verkhovna Rada of Ukraine (1997), The Law of Ukraine "On local government in Ukraine", available at: http://zakon3.rada.gov.ua/laws/show/280/97-vr (Accessed 20 Dec 2018).

10. Blauh, M. (2001), Ekonomichna teoriia v retrospektyvi [Economic theory in retrospect], "Osnovy", Kyiv, Ukraine.

11. State Statistics Service of Ukraine (2018), available at: http:/ / ukrstat.gov.ua / (Accessed 20 Dec 2018).

12. Treasury of Ukraine (2018), "Report", available at: https://www.treasury.gov.ua/ua/file-storage/vikonannya-derzhavnogo-byudzhetu (Accessed 20 Dec 2018).

13. The regional of fices of Statistics of Ukraine (2018), available at: http://www.ukrstat.gov.ua/work/ region.html (Accessed 20 Dec 2018).

Статтл надійшла до редакцї 28.12.2018 p. 